\title{
NF2 gene expression in sporadic meningiomas: Relation to grades or histotypes real time-PCR study
}

\author{
Anna M. Buccoliero, ${ }^{1}$ Francesca Castiglione, ${ }^{1}$ Duccio R. Degl'Innocenti, ${ }^{1}$ Chiara F. Gheri, ${ }^{1}$ \\ Francesca Garbini, ${ }^{1}$ Antonio Taddei, ${ }^{2}$ Franco Ammannati, ${ }^{3}$ Pasquale Mennonna ${ }^{3}$ and Gian L. Taddei ${ }^{1}$ \\ Departments of ${ }^{1}$ Human Pathology and Oncology, ${ }^{2}$ General Surgery, University of Florence, and ${ }^{3}$ Unit of Neurosurgery, \\ Careggi Hospital, Florence, Italy
}

One of the most common regions involved in the meningiomas tumorigenesis is chromosome $22 q$ where the NF2 gene resides. The deficiency or loss of the $N F 2$ gene product, merlin/schwannomin, plays a role in tumor development and metastatization. Conflicting results have been reported on the prognostic value of merlin in meningiomas. Several studies have indicated NF2 gene inactivation as an early tumorigenic event unrelated to the histological grade or clinical behavior. On the contrary, the NF2 gene alteration rate differs between the different histotypes. A pathogenesis independent from the $N F 2$ gene has been suggested in meningothelial meningiomas. In the present work, we studied the $N F 2$ gene expression through real time-PCR (RT-PCR) in 30 meningiomas. The average of the NF2 gene expression of all meningiomas was considered as reference value. The average of expression of WHO grade I and II meningiomas was higher than the average of all meningiomas, whereas that of WHO grade III meningiomas was lower. When we compared the NF2 gene expression in the different meningioma grades we did not note a significant difference $(P=0.698)$ despite the tendency to decrease from grade I to grade III. The average expression of meningothelial meningiomas was higher than the reference value, and that of non-meningothelial meningiomas was lower. The difference in NF2 gene expression between meningothelial and non-meningothelial meningiomas was statistically significant $(P=0.013)$. Our data supports the finding that alterations in $N F 2$ gene alteration are histotype related but not grade related.

Correspondence: Anna Maria Buccoliero, MD, Dipartimento di Patologia Umana e Oncologia, Università degli Studi di Firenze Viale G.B. Morgagni, 85, 50134 Firenze, Italia. Email: ambuccoliero@unifi.it

Received 11 February 2006; revised and accepted 3 April 2006.
Key words: meningioma, meningothelial, merlin, $N F 2$, RTPCR.

\section{INTRODUCTION}

Meningiomas are frequent intracranial neoplasms (a fourth of all primary tumors in this site) arising from the leptomeningeal covering of the central nervous system (CNS). They preferentially affect middle aged or elderly women. Radiation exposure, hormonal and genetic factors, particularly neurofibromatosis 2 syndrome (NF2), have been implicated in their development and growth. Meningiomas initiation, both in NF2 associated and in sporadic cases, is linked to the inactivation of the members of the protein 4.1 superfamily, that is, NF2 gene product merlin/ schwannomin. Approximately $60 \%$ of sporadic meningiomas are caused by the $\mathrm{LOH}$ on chromosome $22 \mathrm{q} 12$ where the NF2 tumor suppressor gene is localized; no causative gene is known for the remaining $40 \% \cdot{ }^{1-8}$

Within the 4.1 superfamily, merlin shares the highest degree of homology with a subgroup of proteins including ezrin, radixin, and moesin (ERM proteins) that link the actin cytoskeleton (by an actin-binding region in the $\mathrm{COOH}$-terminus) to cell membrane glycoproteins such as $\mathrm{CD} 44$ (by its $\mathrm{NH}_{2}$-terminal residues) in polarized cells. The $\mathrm{NH}_{2}$ - and $\mathrm{COOH}$ - terminal halves of ERM proteins mutually interact intramolecularly to suppress their binding activities. The $\mathrm{COOH}$ - terminal threonine phosphorylation maintains ERM proteins in the active state by suppressing the intramolecular interaction..$^{5,7,910}$ The region of the merlin with the greatest structural similarity to the ERM proteins correspond to the its $\mathrm{NH}_{2}$-terminal two-thirds. The merlin $\mathrm{COOH}$-terminus lacks the conventional actinbinding region of the ERM proteins. Contrary to ERM proteins, merlin interacts with F-actin through the 
$\mathrm{NH}_{2}$-terminus. ${ }^{5,9,11-14}$ The similarity of merlin with the ERM proteins indicates that its functions may be related to those of the ERM proteins: organization of membrane extensions and cell adhesion, membrane traffic, and cell signaling. Indeed, merlin interacts, either directly or indirectly, with components of cell junctions and with a number of proteins influencing cell-growth regulation, including paxillin, erbB2, p21-activate kinase, and p53 (through MDM2 degradation). Biochemical studies showed that in the CNS merlin also forms a complex with integrin $\beta 1$ and with Caspr/paranodin, an essential neuronal component of paranodal axoglial junctions. ${ }^{5,7,9,10,13,15-17}$

Several experimental data demonstrated that merlin overexpression results in a significant decrease in cell proliferation, reversion of Ras-induced transformation, and reduction in tumor formation in nude mice. In contrast, the inactivation of the NF2 gene leads to the development of cancer especially through loss of the contact-dependent inhibition of the growth. ${ }^{13,14,18,19}$ The majority of the mutations identified in the NF2 gene, result in a truncation of the protein and are clinically associated with a severe phenotype; occasionally missense mutations associated with a mild phenotype may occur.

The alterations in merlin functions did not show an incontrovertible prognostic value in meningiomas. They occurred in transitional and fibroblastic meningiomas more often than in meningothelial variant.

In the present work, we studied the NF2 gene expression through real time-PCR (RT-PCR) in a group of 30 meningiomas and we evaluated its possible correlation with tumor grade and histotype.

\section{MATERIALS AND METHODS}

\section{Patients}

Tissue specimens were obtained from 30 patients affected by meningiomas surgically treated at the Neurosurgical Service (Careggi Hospital, Florence, Italy) in which fresh tumoral tissue was available for the RT-PCR. Seven (23\%) were from men and $23(77 \%)$ were from women. Average age at the time of the surgery was 54 years (range 29-76). Twenty-nine (97\%) meningiomas were intracranial (one of which was intraventricular; case no. 22 Table 1), the remaining (3\%) case was spinal meningioma (case no. 3; Table 1). Two meningiomas (7\%) were relapsed tumors (case no.s 27, 28 Table 1); two meningiomas (7\%) had multiple localizations (case no.s 1, 6 Table 1).

\section{Real-time PCR}

From each fresh surgical specimen we selected a fragment macroscopically representative of the tumor. Successively, we cut it in half: from one half several $5-\mu \mathrm{m}$ frozen sections
Table 1 Histopathology and RT-PCR results

\begin{tabular}{|c|c|c|c|}
\hline \multirow[t]{2}{*}{ Case } & \multicolumn{2}{|c|}{ Histopathology } & \multirow[t]{2}{*}{ RT-PCR } \\
\hline & Who grade & Histotype & \\
\hline 1 & I & Fibrous & -0.174 \\
\hline 2 & I & Fibrous & -0.896 \\
\hline 3 & I & Fibrous & 0.461 \\
\hline 4 & I & Fibrous & -0.198 \\
\hline 5 & I & Fibrous & -0.365 \\
\hline 6 & I & Fibrous & 0.501 \\
\hline 7 & I & Fibrous & -0.037 \\
\hline 8 & I & Fibrous & -0.219 \\
\hline 9 & I & Meningothelial & 0.361 \\
\hline 11 & I & Meningothelial & 0.385 \\
\hline 12 & I & Meningothelial & 0.432 \\
\hline 13 & I & Meningothelial & 0.376 \\
\hline 14 & I & Meningothelial & 0.339 \\
\hline 15 & I & Meningothelial & 0.09 \\
\hline 16 & I & Secretory & 0.277 \\
\hline 17 & I & Transitional & -0.054 \\
\hline 18 & I & Transitional & -0.372 \\
\hline 19 & I & Transitional & -0.051 \\
\hline 20 & I & Angiomatous & 0.08 \\
\hline 21 & II & Atypical & 0.457 \\
\hline 22 & II & Atypical & -0.337 \\
\hline 22 & II & Atypical & 0.07 \\
\hline 23 & II & Atypical & -0.326 \\
\hline 24 & II & Chordoid & 0.265 \\
\hline 25 & III & Anaplastic & -0.298 \\
\hline 26 & III & Anaplastic & -0.275 \\
\hline 27 & III & Anaplastic & 0.226 \\
\hline 28 & III & Anaplastic & -1.277 \\
\hline 29 & III & Anaplastic & 0.487 \\
\hline 30 & - & Oncocytic & 0.055 \\
\hline
\end{tabular}

stained with hematoxylin-eosin (HE) were obtained to verify the adequacy of the specimens selected for RT-PCR (presence of pathological tissue only); the other half was immersed in RNAlater (QIAGEN, Valencia, CA, USA) and kept overnight at $+4^{\circ} \mathrm{C}$ and finally stored at $-80^{\circ} \mathrm{C}$ until it was analyzed. The thawed specimens were cut into small pieces and homogenized. After proteinase $\mathrm{K}$ digestion $\left(250 \mu \mathrm{g} / \mathrm{mL}\right.$ for $1 \mathrm{~h}$ at $\left.37^{\circ} \mathrm{C}\right)$, total RNA was isolated with 6100 Nucleic Acid PrepStation (Applied Biosystems, Foster City, CA, USA). The RNA concentration and purity in preparations was assessed spectrophotometrically by measuring their absorbance at $260 \mathrm{~nm}$ and $280 \mathrm{~nm}$. The RNA fragmentation state was estimated with ethidium bromidestained $1 \%$ agarose gel. The fragment length of RNA was $>650$ bp in all cases. Total RNA (500 ng) was subject to reverse transcription to cDNA using High Capacity cDNA Archive Kit (Applied Biosystems). The quantitative RTPCR was performed on an ABI PRISM 7000 Sequence Detector System (Applied Biosystems). PCR products for NF2 were detected using gene-specific primers and probes labeled with reporter day FAM (Assay on Demand, Applied Biosystems). GAPDH was used as endogenous control gene for normalization. PCR reactions were carried out in 96-well plate with $20 \mu \mathrm{L}$ per well using $1 \times$ Taq- 
Man Universal PCR MasterMix. After an incubation for $2 \mathrm{~min}$ at $50^{\circ} \mathrm{C}$ and $10 \mathrm{~min}$ at $95^{\circ} \mathrm{C}$, the reaction continued for 50 cycles at $95^{\circ} \mathrm{C}$ for $15 \mathrm{~s}$ and $60^{\circ} \mathrm{C}$ for $1 \mathrm{~min}$.

The $2^{-\Delta \Delta \mathrm{Ct}}$ method described by Livak and Schmittgen was used to calculate fold expression levels relative to the average value of the all meningiomas RNA specimens (the calibrator).$^{20}$ We chose the average expression of all meningiomas as reference value to especially stress the stronger difference of expression.

\section{Histopathology}

After the drawing of the small samples for RT-PCR, the remaining tissues were routinely fixed in $10 \%$ buffered formalin and embedded in paraffin. Five- $\mu \mathrm{m}$ thick sections were stained with HE for morphological evaluation. The diagnostic criteria used were those indicated by the most recently revised World Health Organization (WHO) classification of tumors of the nervous system. ${ }^{21}$

\section{Statistical analysis}

The shift of expression level of NF2 gene as estimated through relative RT-PCR was calculated according to the Kruskal-Wallis test. Data analysis was performed using Primit Version 3.03 (McGraw-Hill, Milan, Italy, 1994) statistical package. A $P$-value $\leq 0.05$ was considered to be statistically significant.

\section{RESULTS}

\section{Cases and RNA extraction}

Nineteen $(63 \%)$ lesions were WHO grade I meningiomas (eight fibrous, six meningothelial, three transitional, one secretory and one angiomatous) (Fig. 1), five (17\%) were WHO grade II meningiomas (four atypical and one chor-

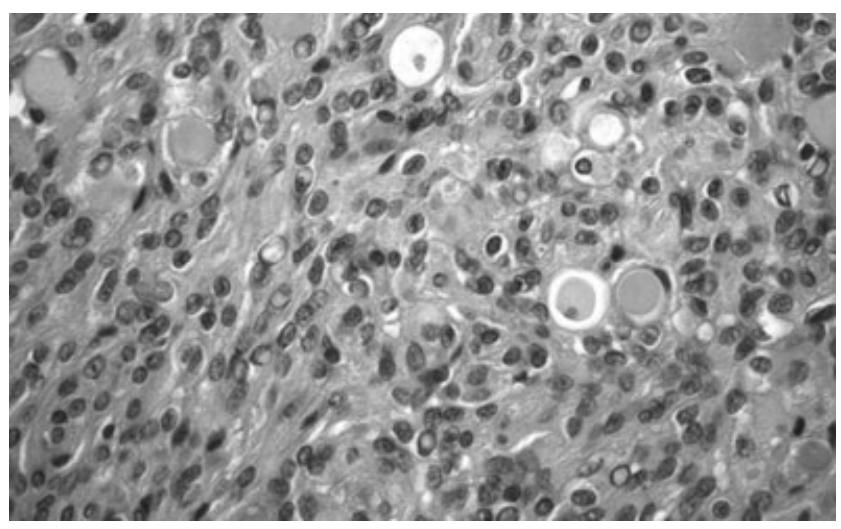

Fig. 1 Secretory meningioma showing intra or extracytoplasmic round hyaline and eosinophilic bodies in a lesion otherwise classifiable as meningothelial meningioma. HE. Original magnification $400 \times$. doid) (Figs 2,3), five (17\%) were WHO grade III meningiomas (anaplastic) (Fig. 4) and one (3\%) was an oncocytic meningioma, a novel uncategorized rare variant showing oncocytic differentiation (wide granular cytoplasm full of numerous swollen mitochondria) and uncertain prognosis (Fig. 5). ${ }^{22}$

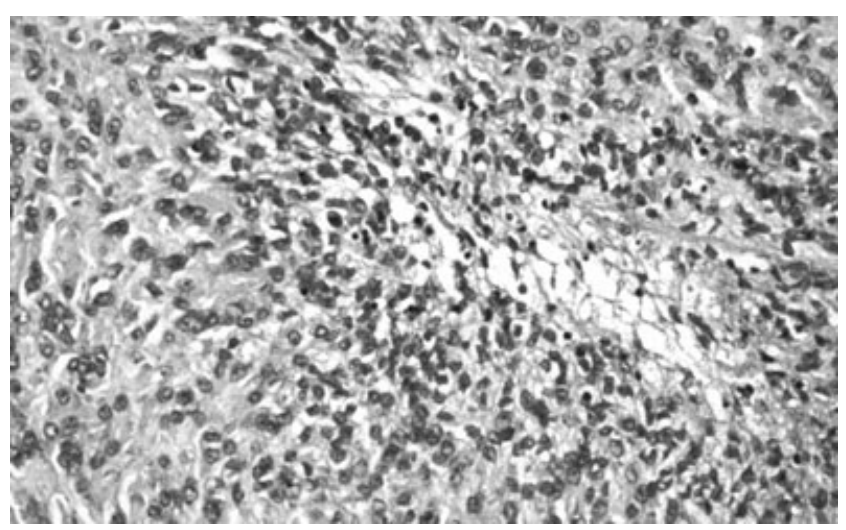

Fig. 2 WHO II meningioma. Atypical meningioma showing foci of necrosis. HE. Original magnification $200 \times$.

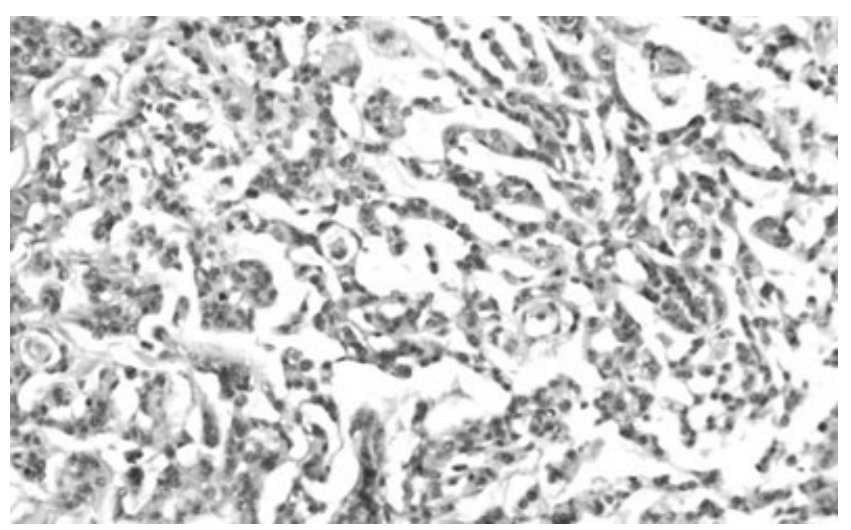

Fig. 3 WHO II meningioma. Chordoid meningioma. HE. Original magnification $200 \times$.

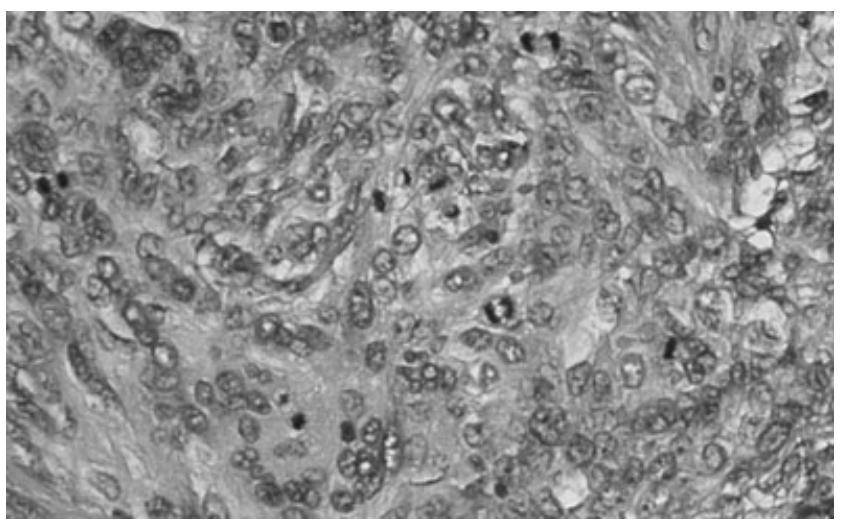

Fig. 4 WHO III meningiomas. Anaplastic meningiomas showing numerous mitoses. HE. Original magnification 400×.

(C) 2007 Japanese Society of Neuropathology 
Fig. 5 Oncocytic meningioma: the lesion is composed of sheets (A) of rounded cells with wide granular eosinophilic cytoplasm (B). HE. Original magnification $100 \times$ (left), $400 \times$ (right).
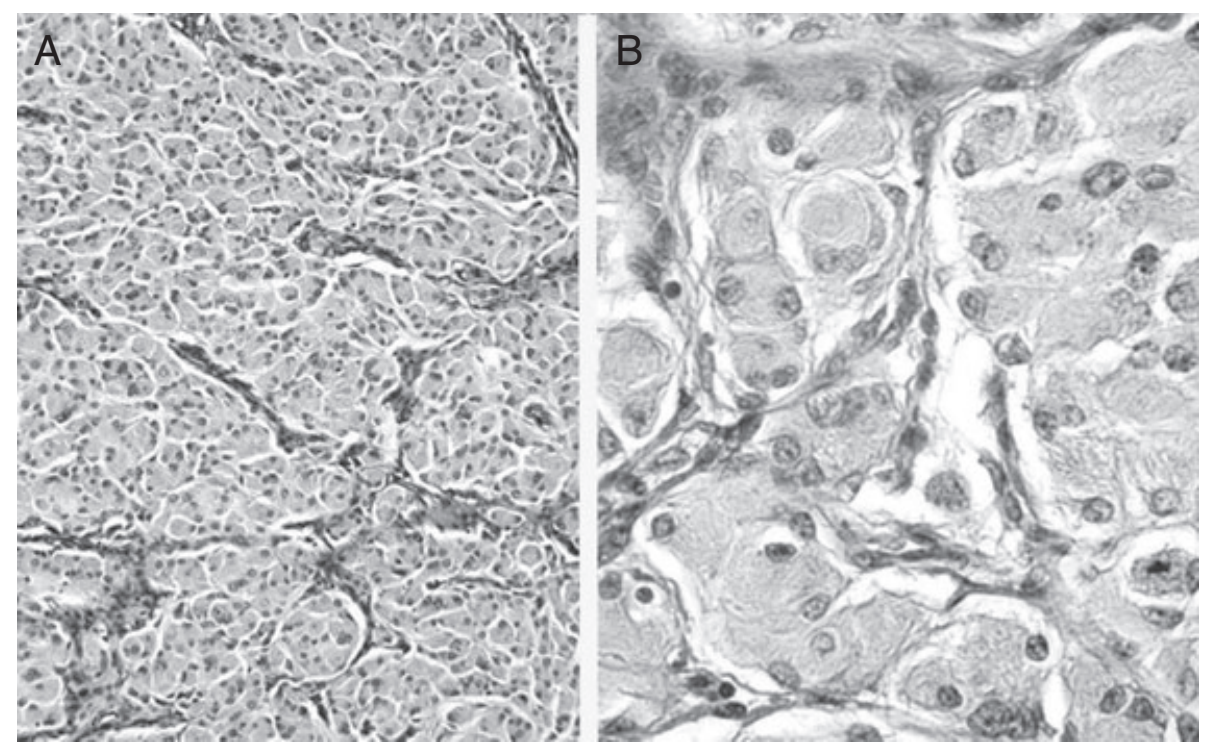

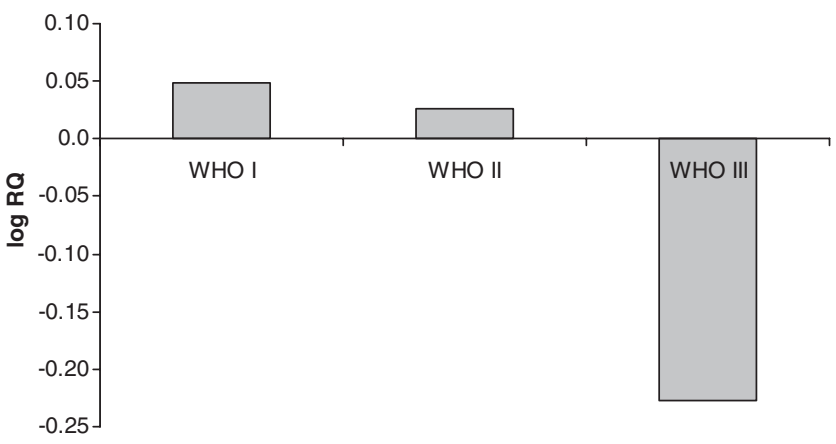

Fig. 6 NF2 relative expression in WHO grade I, II and III meningiomas as compared with the average expression of all meningiomas.

\section{Real-Time PCR}

RNA extraction was successful in all samples. The NF2 gene expression in all types of meningiomas was compared to the average value of expression (reference value) of the all meningiomas (Table 1 ).

The mean of NF2 relative gene expression of all WHO grade I and II meningiomas showed an expression higher ( 0.049 and 0.025 , respectively) than the average of all meningiomas used as calibrator. The mean of $N F 2$ relative gene expression of WHO grade III meningiomas showed an expression lower (-0.227) than the calibrator (Fig. 6). The only oncocytic meningioma had an expression higher than the calibrator $(0.055)$. When we compared the NF2 gene expression between the different meningioma grades we did not note a significant difference $(P=0.698)$ despite the tendency to decrease from grade I to grade III (Fig. 6). Analogously, there were not differences between the two relapses and the primary meningiomas $(P=0.360)$. The mean of $N F 2$ relative gene expression of non-meningoth- elial meningiomas was lower $(-0.100)$ than the reference value, that of meningothelial meningiomas (we considered together meningothelial meningiomas and the only one secretory meningioma because secretory meningioma is an infrequent meningioma subtype characterized by an advanced epithelial differentiation in a lesion frequently otherwise classifiable as meningothelial meningiomas, ${ }^{23}$ Fig. 1) was higher (0.306). Meningothelial meningiomas (meningothelial meningiomas and secretory meningioma) exhibited significantly higher NF2 gene expression compared with those of non-meningothelial meningiomas $(P=0.013$ when all meningiomas were considered; $P=0.018$ when WHO grade I meningiomas only were considered). Within each group of meningiomas, there is a high variability of relative expression of each single case (Table 1; Fig. 7).

\section{DISCUSSION}

In previous years, the genetic events involved in the molecular pathogenesis of meningiomas begun to be defined. One of the most common regions involved in the meningiomas tumorigenesis is chromosome $22 \mathrm{q}$ where the $N F 2$ gene resides. ${ }^{24,25}$ Inactivating mutations of both alleles are required in the tumorigenesis. ${ }^{26,27}$ In the familial setting (NF2 syndrome), a germline mutation inactivates the first allele; the second allele is inactivated by loss of chromosome or part of chromosome 22 on which the gene is located in target cells. Somatic biallelic NF2 gene mutations are implied for sporadic meningiomas. In some cases the merlin expression has been demonstrated to be reduced or absent also in absence of biallelic NF2 gene inactivation suggesting that a post-translational regulation of merlin may be involved in the loss of its expression. ${ }^{28-30}$ 


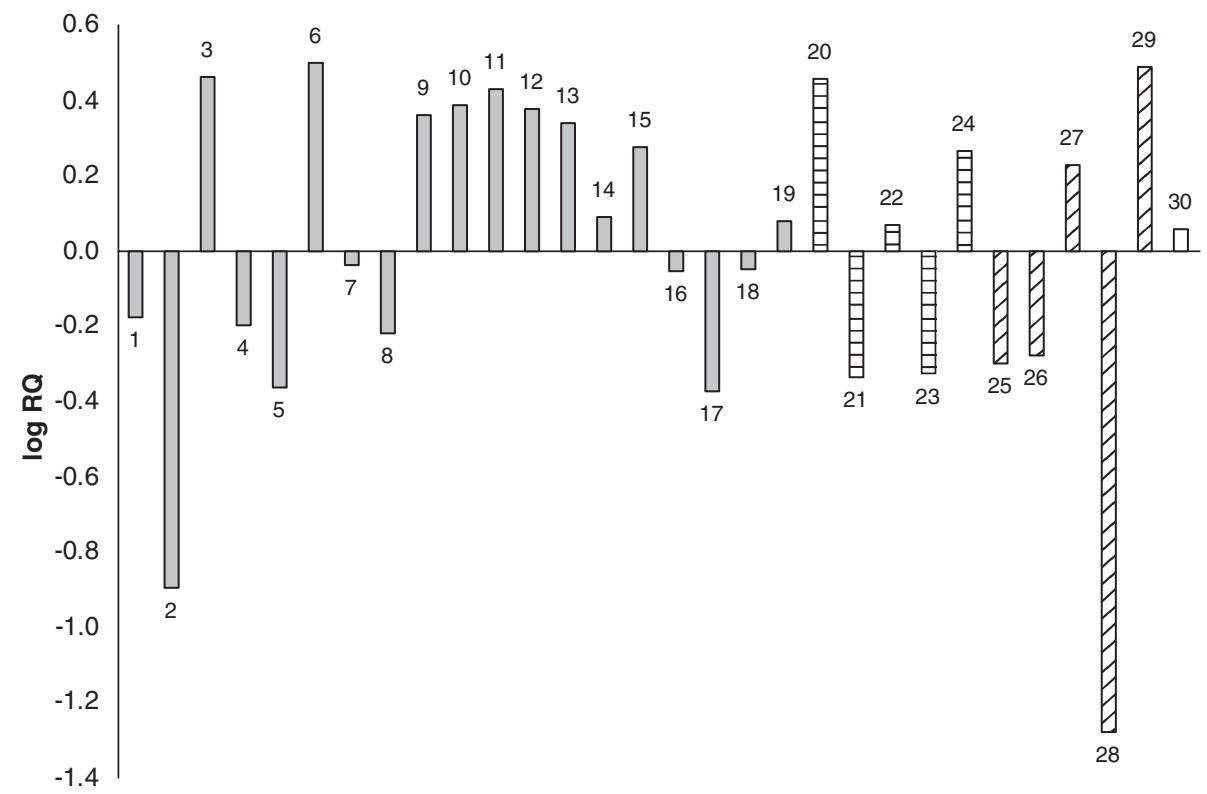

Fig. 7 NF2 relative expression case per case in WHO grade I $(\square)$, grade II (E) and grade III meningiomas $(\nabla)$ and in oncocytic meningioma (case $\mathrm{n}^{\circ}$ $30)$.
The majority of the NF2 gene mutations results in a non-functional, truncated protein. ${ }^{31}$ The mutations like frameshift, nonsense and splice site alterations in the $\mathrm{NH}_{2}$ terminal domain give rise to truncated or abnormal protein in both $\mathrm{NH}_{2}$ - and $\mathrm{COOH}$-terminal domains. Other mutations exclusively occur in the $\mathrm{COOH}$-terminal domain. The consequent loss of this region confers tumorigenicity confirming that $\mathrm{COOH}$-terminus is essential for efficient antioncogenic activity. ${ }^{32}$ The inability of merlin with altered $\mathrm{COOH}$-terminus to form intramolecular complexes was associated with a failure to negatively regulate cell growth. ${ }^{33}$ The in-frame deletions and missense mutation involving one or few amino acids cause the loss of merlin function. ${ }^{1}$ Some cases with NF2 gene mutations, not showing merlin presence, ${ }^{31}$ suggest a possible decrease stability of the mutant protein and consequently a difficult detection; moreover recent analysis of the only NF2 gene missense mutation demonstrated only a mildly decreased protein half-life. ${ }^{30}$ It has been suggested that in some meningiomas an abnormal activation of $\mu$-calpain may cause merlin loss by his proteolytic activity. ${ }^{34}$ Oxidative-stress might cause $\mu$-calpain activation. Based on these findings, Kaneko et al. proposed an interesting scheme of meningioma tumorigenesis: first, the oxidative stress (e.g., due to aging) induces $\mathrm{Ca}^{2+}$ mobilization, and $\mathrm{Ca}^{2+}$ activates calpain; successively, the autolyzed and activated calpain translocates from the cytoplasm to the plasma membrane; merlin is then cleaved by the activated calpain, and this cleavage product presumably transfers into the nucleus via the perinuclear cytoplasm; as a consequence of this the signal pathway for cell adhesion and the contact inhibition may be impaired, leading to meningiomas. ${ }^{35}$
Conflicting results have been reported with regard to the possible prognostic value of merlin in meningiomas. Several studies suggest that merlin loss is relatively equally distributed among clinicopathological subsets. Indeed, it is not associated with recurrences or with histopathological features predicting unfavorable outcomes (i.e., brain invasion, cellular proliferation, or anaplasia). Actually, the majority of the previous studies have indicated the NF2 protein inactivation as an early tumorigenic event in sporadic and NF2-syndrome associated meningiomas. ${ }^{3,5,7,27,36,37}$

In contrast, the $N F 2$ gene mutation rate differs between histological subtypes of meningiomas. In 1995, Wellenreuther et al. demonstrated that NF2 gene mutation occurs in $83 \%$ of transitional meningiomas and in $70 \%$ of fibroblastic meningiomas but in only $25 \%$ of meningothelial meningiomas. ${ }^{36}$ More recently the hypothesis of a different molecular route of pathogenesis independent of the NF2 gene pathway in meningothelial meningiomas has been further supported. , $^{\text {,36-39 }}$

RT-PCR is an accurate method for the determination of levels of specific DNA and RNA sequences in tissue samples. The amount of a specific RNA sequence consents to evaluate the expression of a specific gene. Nevertheless, the gene expression analyses do not assess the integrity or the functionality of the translated protein. Consequently, in our study we could not evaluate the stability and the functionality of merlin. Nevertheless, our results on $N F 2$ gene expression in different WHO grade meningiomas are in agreement with the published literature. Although the mean NF2 gene expression of the cases that we studied seems to be reducing from WHO I to WHO III, there is an extreme variability from case to case in each group. 
Furthermore, analogously to previous studies that support an NF2 gene-independent pathogenesis histotype, we observed a statistical difference in the NF2 gene expression between meningothelial (meningothelial meningiomas and secretory meningioma) and non-meningothelial meningiomas. Secretory meningioma showed high NF2 expression, meaning that the similarity between these two histotypes might be both morphological and molecular.

In conclusion our results indicate that NF2 gene expression alterations are not a mark of malignance in meningiomas and that meningothelial meningioma may arise independently of $N F 2$ gene alterations.

\section{REFERENCES}

1. De Vitis LR, Tedde A, Vitelli F et al. Screening for mutations in the neurofibromatosis type 2 (NF2) gene in sporadic meningiomas. Hum Genet 1996; 97: 632637.

2. Perry A, Gutmann DH, Reinfenberger G. Molecular pathogenesis of meningiomas. J Neurooncol 2004; 70: 183-202.

3. Perry A, Cai DX, Sheithauer B et al. Merlin, DAL-1, and progesterone receptor expression in clinicopathologic subsets of meningioma: a correlative immunohistochemical study of 175 cases. J Neuropath Exp Neur 2000; 10: 872-879.

4. Luis E, Gutman DH. Meningioma: an update. Curr Opin Neurol 2004; 17: 687-692.

5. Robb VA, Li W, Gascard P, Perry A, Mohandas N, Gutmann DH. Identification of a third Protein 4.1 tumor suppressor, Protein 4.1R, in meningioma pathogenesis. Neurobiol Dis 2003; 13: 191-202.

6. Ueki K, Wen-Bin C, Narita Y, Asai A, Kirino T. Tight association of loss of merlin expression with loss of heterozygosity at chromosome $22 \mathrm{q}$ in sporadic meningiomas. Cancer Res 1999; 59: 5995-5998.

7. Gutmann DH, Donahoe J, Perry A et al. Loss of DAL1, a protein 4.1-related tumor suppressor, is an important early event in the pathogenesis of meningiomas. Hum Mol Genet 2000; 10: 1495-1500.

8. Gutmann DH, Giordano MJ, Fishback AS, Guha A. Loss of merlin expression in sporadic meningiomas, ependymomas and schwannomas. Neurology 1997; 49: 267-270.

9. Gutmann DH. The neurofibromatosis: when less is more. Hum Mol Genet 2001; 10: 747-755.

10. Rangwala R, Banine F, Borg JP, Sherman LS. Erbin regulates mitogen activated protein (MAP) kinase activation and MAP kinase-dependent interactions between merlin and adherens junction protein complexes in schwann cells. J Biol Chem 2005; 280: 11790 11797.
11. Xu HM, Gutmann DH. Merlin differentially associates with the microtubule and actin cytoskeleton. J Neurosci Res 1998; 51: 403-415.

12. Brault E, Gautreau A, Lamarine M, Callebaut I, Thomas G, Goutebroze L. Normal membrane localization and actin association of the NF2 tumor suppressor protein are dependent on folding of its N-terminal domain. J Cell Sci 2001; 114: 1901-1912.

13. Grönholm M, Teesalu T, Tyynelä $\mathrm{J}$ et al. Characterization of the NF2 protein merlin and the ERM protein ezrin in human, rat, and mouse central nervous system. Mol Cell Neurosci 2005; 28: 683-693.

14. James MF, Manchanda N, Gonzalez-Agosti C, Hartwig JH, Ramesh V. The neurofibromatosis 2 protein product merlin selectively binds F-actin but not Gactin, and stabilizes the filaments through a lateral association. Biochem J 2001; 356: 377-386.

15. Ramesh V. Merlin and the ERM proteins in Schwann cells, neurons and growth cones. Nat Rev Neurosci 2004; 5: 462-470.

16. Kim H, Kwak NJ, Lee JY et al. Merlin neutralizes the inhibitory effect of Mdm2 on p53. J Biol Chem 2004; 279: 7812-7818.

17. Denisenko-Nehrbass N, Goutebroze L, Galvez T et al. Association of Caspr/paranodin with tumour suppressor schwannomin/merlin and beta1 integrin in the central nervous system. J Neurochem 2003; 84: 209-221.

18. Lallemand D, Curto M, Saotome I, Giovannini M, McClatchey AI. NF2 deficiency promotes tumorigenesis and metastasis by destabilizing adherens junctions. Genes Dev 2003; 17: 1090-1100.

19. Chen Y, Gutman DH, Haipek CA, Martinsen BJ, Bronner-Fraser M, Krull CE. Characterization of chicken NF2/merlin indicates regulatory roles in cell proliferation and migration. Dev Dynam 2004; 229: 541-554.

20. Livak KJ, Schmittgen TD. Analysis of relative gene expression data using real-time quantitative PCR and the $2(-\Delta \Delta \mathrm{C}(\mathrm{T}))$ method. Methods $2001 ; 25$ : 402-408.

21. Louis DN, Scheithauer BW, Budka $\mathrm{H}$ et al. Meningiomas. In: Kleihues P, Cavenee K (eds). World Health Organization Classification of Tumors. Pathology and Genetics of Tumours of the Nervous System. Lyon: IARC Press, 2000; 176-189.

22. Caldarella A, Buccoliero AM, Marini M, Taddei A, Mennonna P, Taddei GL. Oncocytic meningioma: a case report. Pathol Res Pract 2002; 198: 109-113.

23. Ironside JW, Moss TH, Louis DN et al. Diagnostic Pathology of Nervous System Tumours. London: Churchill Livingstone, 2002.

24. Ruttledge MH, Sarrazin J, Rangaratnam S et al. Evidence for the complete inactivation of the NF2 gene in the majority of sporadic meningiomas. Nat Genet 1994; 6: $180-184$. 
25. Lekanne Deprez RH, Bianchi AB, Groen NA et al. Frequent NF2 gene transcript mutations in sporadic meningiomas and vestibular schwannomas. Am J Hum Genet 1994; 54: 1022-1029.

26. McClatchey AI, Saotome I, Ramesh V, Gusella JF, Jacks $\mathrm{T}$. The Nf2 tumor suppressor gene product is essential for extraembryonic development immediately prior to gastrulation. Genes Dev 1997; 11: 1253-1265.

27. Kalamarides M, Niwa-kawakita M, Leblois $\mathrm{H}$ et al. NF2 gene inactivation in arachnoidal cells is ratelimiting for meningioma development in mouse. Gene Dev 2002; 16: 1060-1065.

28. Stemmer-Rachamimov AO, Xu L, Gonzalez-Agosti C et al. Universal absence of merlin, but not other ERM family members in schwannomas. Am J Pathol 1997; 151: 1649-1654.

29. Lee JH, Sundaram V, Stein DJ, Kinney SE, Stacey DW, Golubic M. Reduced expression of schwannomin/merlin in human sporadic meningiomas. Neurosurgery 1997; 40: 578-587.

30. Gutmann DH, Geist RT, Xu HM, Kim JS, SaporitoIrwin S. Defect in neurofibromatosis 2 protein function can arise at multiple levels. Hum Mol Genet 1998; 7: 335-345.

31. Den Bakker MA, van Tilborg AAG, Kros Jm Zwarthoff EC. Truncated NF2 proteins are not detected in meningiomas and schwannomas. Neuropathology 2001; 21: 168-173.

32. Tikoo A, Varga M, Ramesh V, Gusella J, Maruta H. An anti-Ras function of neurofibromatosis type 2 gene product (NF2/Merlin). J Biol Chem 1994; 269: $23387-$ 23390.

33. Sherman L, Xu HM, Geist RT et al. Interdomain binding mediates tumor growth suppression by the NF2 gene product. Oncogene 1997; 15: 2505-2509.

34. Kimura $\mathrm{Y}$, Koga $\mathrm{H}$, Araki $\mathrm{N}$ et al. The involvement of calpain-dependent proteolysis of the tumor suppressor NF2 (merlin) in schwannomas and meningiomas. Nat Med 1998; 4: 915-922.

35. Kaneko T, Yamashima T, Tohma Y et al. Calpaindependent proteolysis of merlin occurs by oxidative stress in meningiomas: a novel hypothesis of tumorigenesis. Cancer 2001; 92: 2662-2672.

36. Wellenreuther R, Kraus JA, Lenartz D et al. Analysis of the neurofibromatosis 2 gene reveals molecular variants of meningiomas. Am J Pathol 1995; 146: 827832.

37. Perry A, Giannini C, Raghavan R et al. Aggressive phenotypic and genotypic features in pediatric and NF-2.associated meningiomas: a clinicopathologic study of 53 cases. J Neuropathol Exp Neurol 2001; 10: 994-1003.

38. Wellenreuther R, Waha A, Vogel Y et al. Quantitative analysis of neurofibromatosis type 2 gene transcript in meningiomas supports the concept of distinct molecular variants. Lab Invest 1997; 6: 601-606.

39. Evans JJ, Jeun SS, Lee JH et al. Molecular alterations in the neurofibromatosis type 2 gene and its protein rarely occurring in meningothelial meningiomas. $J$ Neurosurg 2001; 94: 111-117. 